\title{
Eelgrass seed dispersal via floating generative shoots in the Dutch Wadden Sea: a model approach
}

\author{
Paul L. A. Erftemeijer ${ }^{1, *}$, Jan K. L. van Beek ${ }^{1}$, Caroline A. Ochieng ${ }^{2}$, Zwanette Jager ${ }^{3}$, \\ Hans J. $\operatorname{Los}^{1}$
}

${ }^{1}$ WL/Delft Hydraulics, PO Box 177, 2600 MH Delft, The Netherlands

${ }^{2}$ Jackson Estuarine Laboratory, University of New Hampshire, 85 Adams Point Road, Durham, New Hampshire 03824, USA ${ }^{3}$ National Institute for Coastal and Marine Management/RIKZ, PO Box 207, 9750 AE Haren, The Netherlands

\begin{abstract}
Potential long-distance dispersal of eelgrass seeds via floating generative shoots from a 256 ha meadow in the Ems Estuary (Wadden Sea) was studied by means of computer-simulation modelling. Flowering shoot density (peaking at $7.8 \mathrm{~m}^{-2}$ ) and total seed production (1094 million seeds $\mathrm{yr}^{-1}$ ) of this meadow was determined in the field and used as model input. Dispersal of floating generative shoots dislodged by increased water turbulence during autumn was modelled using a 3D transport model (Delft3D-WAQ). Transport of eelgrass seeds contained in floating reproductive shoots with the prevailing hydrodynamic regime revealed maximum dispersal distances of up to $130 \mathrm{~km}$ from the source of seed production. The effect of wind speed and direction on seed transport was assessed by applying a wind drag function ( $3 \%$ of wind speed) on surface currents in the model using actual wind data from 10 consecutive years (1993 to 2002). Main transport direction under average autumn wind conditions was northeastward. Easterly winds (occurring at an average frequency of $15 \%$ ) were responsible for some westward transport of eelgrass seeds (at densities $>0.2$ seeds $\mathrm{m}^{-2}$ ) up to $20 \mathrm{~km}$ from the estuary. Westward eelgrass colonization of suitable areas in the Dutch Wadden Sea appears to be limited by seed supply due to transport limitations posed by the prevailing hydrodynamic regime. Extreme events, such as prolonged Eastern storms, might promote seed dispersal further westwards, allowing for natural recovery of eelgrass in this area; this theory is supported by observations of localized eelgrass patches up to $40 \mathrm{~km}$ west of the estuary.
\end{abstract}

KEY WORDS: Seed dispersal · Zostera marina $\cdot$ Transport modelling $\cdot$ Wind effects $\cdot$ Recruitment limitation · Wadden Sea

\section{INTRODUCTION}

Meadows of eelgrass Zostera marina L. once covered up to $150 \mathrm{~km}^{2}$ in the Dutch part of the Wadden Sea (Van Goor 1919). Changes in the hydrographic conditions (due to the construction of a causeway - the Afsluitdijk), deterioration of the water quality (especially turbidity) due to eutrophication and pollution, and possibly an epidemic outbreak of wasting disease caused widespread eelgrass degradation until $<1 \mathrm{~km}^{2}$ remained in the early 1970s (Giesen et al. 1990). Despite significant improvements in water quality, which no longer inhibits eelgrass growth at present (Jager et al. 2002), recovery of eelgrass populations in the Dutch part of the Wadden Sea thus far has been minimal (De Jonge et al. 2000).

As the few remaining eelgrass stands in the Dutch Wadden Sea consist almost entirely of annual populations, most vegetation dies off during winter. The maintenance of existing meadows and the colonization of new habitats suitable for eelgrass growth in the Dutch Wadden Sea therefore depend almost entirely on seed dispersal and survival and seedling establishment. Indeed, it is becoming increasingly apparent that recolonisation may be limited in many areas by propagule supply and not water quality (Orth et al. 2006). Unlike many terrestrial annual species and some tropical seagrass species for which a seed bank 
exists (McMillan 1991), Zostera marina seeds are not viable beyond their first season (Orth et al. 2000). Successful eelgrass regeneration will therefore depend on the dispersal of seeds from existing eelgrass stands, the subsequent retention of these seeds in potentially suitable locations, and their successful germination and establishment (Hootsmans et al. 1987, Greve et al. 2005).

The potential for reproductive shoots of eelgrass to become dislodged and raft over great distances was investigated in Chesapeake Bay (USA) by Harwell \& Orth (2002). Dislodgement of reproductive shoots under the influence of extreme hydrodynamic conditions depended on their biomechanical properties, such as breaking stress, breaking strain, elasticity modulus and toughness (Patterson et al. 2001). Once detached, floating reproductive shoots were found to remain positively buoyant for 2 to $3 \mathrm{wk}$ and to retain mature seeds for up to $3 \mathrm{wk}$ before release, allowing for substantial transport of seed-containing, floating generative shoots from source populations by a combination of tidal currents and wind influences (Harwell \& Orth 2002).

Recent genetic and field studies have shown greater variation in recruitment behaviour (dormancy, dispersability, germination) of seagrass seeds than previously suspected (Inglis 2000). A recent study on the molecular genetic structure of Northern Atlantic eelgrass populations found that a transition from weak to strong isolation-by-distance occurred at $\sim 150 \mathrm{~km}$ among northern European populations, suggesting this scale as the natural limit for dispersal within the metapopulation (Olsen et al. 2004). Different seagrass species adopt differing seed dispersal strategies relating to their life histories and rates of recruitment. There is a paucity of information on the effective dispersal distances and recruitment success achieved by these different strategies (Inglis 2000). Most accounts of long-distance seagrass dispersal in the literature are qualitative and the role of rare storm events in transporting seeds has never been investigated (Orth et al. 1994). Very few studies have actually quantified seagrass seed dispersal distance (Orth et al. 1994, Kaldy \& Dunton 1999, Harwell \& Orth 2002, Lacap et al. 2002). In most of these studies, potential dispersal distances were calculated by multiplying mean current flow with the buoyancy period of propagules or seeds. Hydrodynamic modelling was only applied by Orth et al. (1994), who incorporated wind influences, settling velocity, maximum bottom sheer velocities and the critical erosion threshold of seeds in their 3-dimensional hydrographic computer simulation model of eelgrass seed dispersal in York River (Chesapeake Bay, USA).

In this study, we assessed the potential long-distance dispersal of eelgrass seeds (as floating generative shoots) from an existing meadow in the Ems estuary towards other parts of the Dutch Wadden Sea using hydrodynamic modelling, actual wind datasets and field monitoring data. Our aims were to address the following questions: (1) How far can floating reproductive shoots transport eelgrass seeds, and how does this compare with the range of dispersal predicted from population genetics? (2) What is the effect of different wind scenarios on the dispersal behaviour? (3) Does this transport mechanism offer opportunities for natural regeneration of eelgrass in the Dutch Wadden Sea through colonization of unvegetated habitats suitable for eelgrass growth?

\section{MATERIALS AND METHODS}

Eelgrass seed production. This study concentrated on an eelgrass meadow on the Hond/Paap tidal flat in the Ems Estuary in the eastern part of the Dutch Wadden Sea (Fig. 1). This meadow consists of a relatively sparse monospecific vegetation of eelgrass Zostera marina L. that established itself in the 1980s and expanded from an initial 2 ha in 1988 to 256 ha in 2003 (Groeneweg 2003). The meadow - which is an inter-

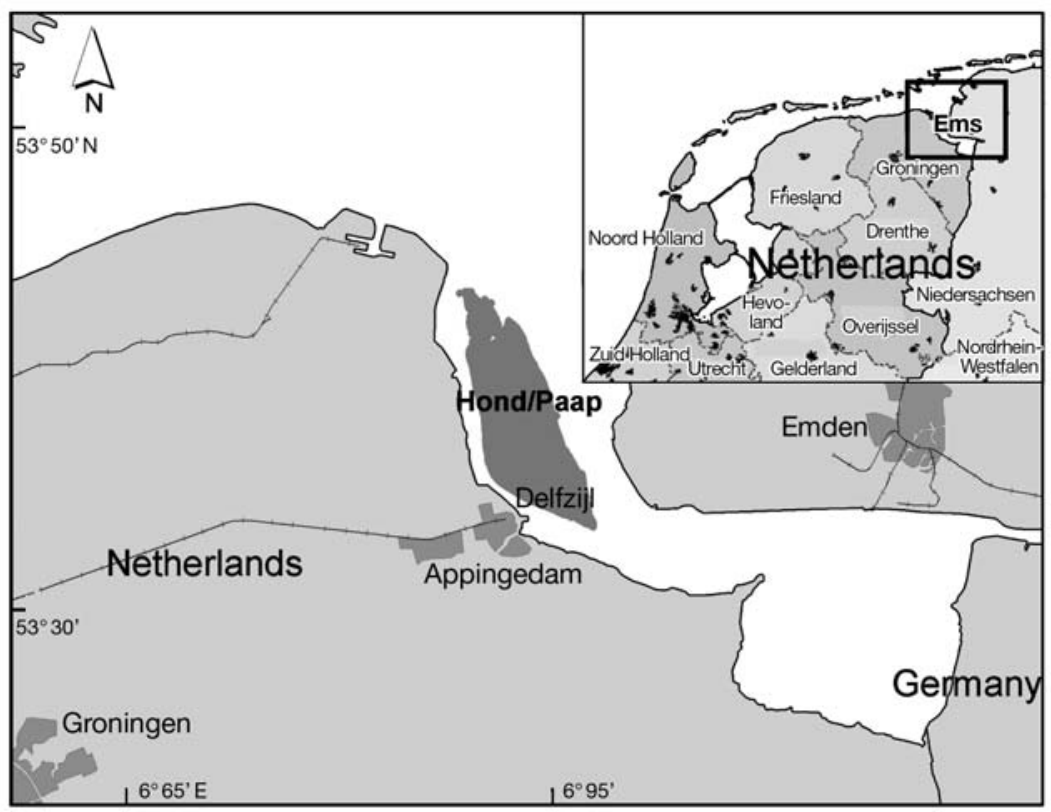

Fig. 1. Study area-Ems Estuary and part of the eastern Dutch Wadden Sea. Dark grey: Hond/Paap tidal flat where the eelgrass meadow was located 
tidal stand largely composed of annual plants, with only $12 \%$ of plants surviving the winter as rhizomewas subject to a detailed monitoring project during 2003 to investigate the impact of dredging activities in the area (Erftemeijer \& Wijsman 2003); this allowed for the collection of field data on seed production.

Field monitoring of the seagrass meadow was carried out in 6 permanent plots $(5 \times 5 \mathrm{~m})$ established randomly in the seagrass bed. During monthly visits, eelgrass shoot density and flowering shoot density $\left(\mathrm{m}^{-2}\right)$ were monitored in the plots (Short \& Coles 2001). Towards the end of the peak flowering period (late September 2003), the number of mature seeds per spathe, the number of spathes per flowering shoot, and the number of flowering shoots per $\mathrm{m}^{2}$ were measured in all plots. The eelgrass meadow on the Hond/Paap is mapped annually on the basis of aerial photograph interpretation (Groeneweg 2003). The actual eelgrass cover in the 6 plots was estimated by the mapping staff during their ground truthing visit to the area in September 2003, to allow for extrapolation of field and mapping data. These data were subsequently used to estimate the total seed production of this meadow. The longevity, turnover and cumulative formation of flowering shoots was not taken into consideration in this study (but see comments in 'Discussion').

Wind data. Data on hourly average wind speed (in $\mathrm{m} \mathrm{s}^{-1}$ ) and wind direction (in degrees) — from the Royal Dutch Meteorological Institute (KNMI) meteorological station at Eelde (ca. $40 \mathrm{~km}$ southwest of Delfzijl) were used for this study. Earlier analysis of $30 \mathrm{yr}$ averages determined that wind speeds measured at this land-based meteorological station deviate $<1.2$ times from actual wind speeds in the lower reaches of the Ems estuary (De Jonge 1995). The main characteristics of the wind conditions in the study area were summarised in a wind rose covering the period of mid-September to mid-November (averaged for the years 1993 to 2002). Actual wind data (hourly averages) of 1993 to 2002 were used in the various model runs.

Hydrodynamic model. Recent advances in computer technology, hydrodynamic modelling, seagrass seed biology and ecology of rafting in the marine environment have opened the way to successfully simulate the transport of marine larvae, seeds and propagules using oceanographic modelling techniques (Sammarco \& Heron 1994, Orth et al. 2006, Thiel \& Haye 2006). The present modelling exercise was carried out using Delft3D. Delft3D is a modelling system that can simulate flows, waves, sediment transports, morphological developments and ecological processes and consists of several modules (Roelvink \& Van Banning 1994, Lesser et al. 2004). Three-dimensional unsteady flow and transport phenomena resulting from tidal and meteorological forcing are simulated in Delft3D-FLOW by solving the well-known shallow-water hydrostatic pressure equations (Stelling 1983, Lesser et al. 2004). The model equations, formulated in orthogonal curvilinear coordinates, are discretised onto a staggered Arakawa-C grid and time-integrated by means of an ADI (Alternating Direction Implicit) numerical scheme in horizontal directions and by Crank-Nicolson along the vertical, which is either discretised by terrain following coordinates ( $\sigma$-transformation) or through horizontal z-layers (Stelling 1983, Leendertse 1987). The solution is mass-conserving at every grid cell and time step. This code is extended with transport of salt and heat content, and with 4 turbulence models, such as the $k-\varepsilon$ model for vertical exchange of horizontal momentum and matter or heat, possibly subjected to density stratification, and other models for lateral mixing. Along the open (sea) boundaries, tidal harmonics for water level or currents and concentration patterns for constituents are imposed. The thus-computed flow and mass-transport patterns can be coupled off-line to other Delft3D modules, such as Delft3D-WAQ (see below). In this off-line coupling, aggregation in time step and/or grid cells is optional for speeding up subsequent analyses. The applicability of Delft3D to modelling of shallow-water hydrodynamics has been proved in a number of studies performed by the Coastal Research Station and others (see e.g. Roelvink \& Van Banning 1994, Luijendijk 2001).

For the present study, hydrodynamic transport was obtained from a $14 \mathrm{~d}$ spring-neap tidal hydrodynamic situation with variable wind forcing obtained from a $14 \mathrm{~d}$ period that was representative for the yearly pattern. This hydrodynamic forcing was used repeatedly throughout the simulation period ( 2 mo: see next section). Two grid layouts covering the southern North Sea (including the Wadden Sea) were designed: a moderately fine grid (ZUNOGROF) with $8710 \mathrm{compu}-$ tational elements and an even finer grid (ZUNOFIJN) with 12317 computational elements and greater resolution in the nearshore zone. For the vertical dimension, the water column was subdivided into 10 layers, using a sigma-coordinated approach to ensure sufficient vertical resolution in the near-coastal zone (Stelling \& Van Kester 1994). The hydrodynamic model was adapted from a model originally developed and calibrated in the Flyland project; it was intended to forecast future effects of an airport island on the coast and waters of the Southern North Sea (Roelvink et al. 2001).

Seed-dispersal modeling. Advective transport of floating rafts of reproductive eelgrass shoots was modelled using Delft3D-WAQ. Delft3D-WAQ is the water quality module of the Delft3D modelling suite. This module contains the physical schematization, calculates transport of substances as a function of advective 
and dispersive transport, processes and loads, accumulates fluxes and computes resulting concentrations for each time-step, includes a large selection of numerical solution schemes, and produces outputs in a standardized way that can easily be processed further, creating graphs and statistics. The actual water system is represented within Delft3D-WAQ by means of computational elements (segments). Transport between segments is derived from dedicated models (e.g. simulated in Delft3D-FLOW). Internally, Delft3D-WAQ multiplies fluxes with concentrations to obtain masses across internal and external boundaries. Delft3D-WAQ has been used successfully in the simulation of dredging plumes, thermal discharges and various water pollution studies (Van Gils et al. 1993, Van der Molen et al. 1994, Ouboter et al. 1997).

For the modelling of eelgrass seed transport, we distinguished 3 different fractions: (1) floating seeds in reproductive eelgrass shoots; (2) suspended seeds; and (3) eelgrass seeds on the bottom. Vertically, the water column in the model was subdivided into 4 layers (through aggregation of the original 10 layers of the hydrodynamic model) covering 10, 40, 40 and $10 \%$ of the water depth, respectively.

Flowering eelgrass shoots (with seeds) were introduced into the top layer of the water column as a floating fraction released from a single grid cell at the edge of the source meadow (Hond/Paap), simulating their dislodgement. A best-case scenario was followed, introducing $100 \%$ of the flowering shoots produced as floating fraction into the model, assuming that all flowering shoots have equal potential to become dislodged.

To simulate the gradual release of seeds from the floating material, the model setup included a firstorder decay of the floating shoots, according to $C_{t}=C_{0}$ $\mathrm{e}^{-k t}$ (in which $k=$ decay constant, $C=$ concentration and $t=$ time). Data on the release rate of seeds from floating shoots, as published by Harwell \& Orth (2002), were used and plotted to derive at an approximate decay constant of 0.075 .

Suspended eelgrass seeds (once released from the floating fraction) were given a settling velocity of $200 \mathrm{~m} \mathrm{~d}^{-1}$ (equivalent to $0.23 \mathrm{~cm} \mathrm{~s}^{-1}$ ). Previous studies (Orth et al. 1994, Lacap et al. 2002) have indicated only minor bottom dispersal of seagrass seeds once sedimented (on the order of a few metres at most). Therefore, resuspension and subsequent bottom dispersal of eelgrass seeds was assumed to be negligible at the scale of the present study.

The model calculations were run for a period of $2 \mathrm{mo}$ (i.e. mid-September until mid-November) following the peak of flowering and coinciding with the period of rapid degradation of the eelgrass meadow (due to dislodgement of shoots), as observed during the field monitoring campaign.
The effect of wind on the dispersal of eelgrass seeds was studied by introducing a wind drag function into the model. The increase in surface water velocity due to wind (wind drag) was taken as $3 \%$ of the wind velocity (Tsanis 1989), as also applied by Harwell \& Orth (2002). This wind drag (using actual wind data) was only applied to the floating material in the top layer of the 3D model. The use of wind drag as 3 to $3.5 \%$ of wind speed in the direction of the wind is also commonly applied in hydrodynamic modelling studies of oil slicks as approximation of drift (Reed et al. 1999).

Sensitivity testing of the model. In order to test the sensitivity of the model outcome to the main input variables and key aspects of the model setup, we performed a series of model runs, varying the following 5 factors: (1) model grid resolution, comparing 2 existing models of the Southern North Sea with different grid resolution: ZUNOGROF with 8710 computational elements, versus ZUNOFIJN with 130 by 308 numerical grid points aggregated in Delft3D-WAQ to 12317 computational elements; (2) fall velocity for seeds once released from the floating flowering shoots $\left(20 \mathrm{~m} \mathrm{~d}^{-1}\right.$ or $\left.200 \mathrm{~m} \mathrm{~d}^{-1}\right)_{i}$ (3) release rate of generative shoots from the source meadow (comparison between an 'all at once' scenario versus a 'gradual release' scenario spread out evenly over a $4 \mathrm{wk}$ period); (4) wind drag (comparison between a model run applying wind drag of a continuous eastern wind of $10 \mathrm{~m} \mathrm{~s}^{-1}$ with a model run without wind drag); and (5) hydrodynamics (comparing model output between runs using average hydrodynamics of one typical spring-neap cycle with runs using hydrodynamics based on actual forcing by meteorological and tidal conditions). Subsequently, the root mean squared error (RMSE) and $\mathrm{r}^{2}$ were computed for the differences in results between model runs (pair-wise comparison) and used as measure of model sensitivity (Sokal \& Rohlf 1995).

Ten year model runs. Taking into account our findings from the sensitivity testing of the model, a final model setup was chosen. Using the field data on total seed production and actual wind data (hourly averages), the model was run 10 times using the actual wind data of the 10 most recent years (1993 to 2002). The resulting variability among the $10 \mathrm{yr}$ was aggregated into a probability map of the dispersal plume around the source meadow.

Potential for natural regeneration. The potential for eelgrass colonization in unvegetated areas suitable for eelgrass growth was calculated in a Geographic Information System (GIS) environment (using the HABITAT model) in 2 different ways. In the first approach, the average seed density was computed for each grid cell by averaging the model outcome of 10 subsequent years (1993 to 2002). To obtain a map of the eelgrass regeneration potential, the average seed density was 
subsequently multiplied with the corresponding suitability index of an existing (GIS-based) Eelgrass Habitat Suitability Map of the Dutch Wadden Sea, based on water depth (low tide exposure), exposure to wave energy, current velocity and salinity (De Jong et al. 2005). In the second approach, this outcome was subsequently multiplied by the 'seed sufficiency,' which was defined as the fraction of years in which seed density exceeded a critical minimum threshold required to obtain a $1 \%$ cover of eelgrass vegetation by the end of the growth season. Areas that receive seed densities below this threshold are not expected to develop significant eelgrass vegetation and are therefore not considered to represent areas with significant potential for natural recolonisation.

\section{RESULTS}

\section{Eelgrass seed production}

The eelgrass population on the Hond/Paap showed a typical seasonal pattern of flowering (Fig. 2). Flowering shoots first appeared in June and were present until October, with peak density in September (mean $7.8 \mathrm{~m}^{-2}$, among population range 2.5 to $16.3 \mathrm{~m}^{-2}$ ). Mean number of spadices per flowering shoot during peak flowering was $12.2 \pm 1.1$ (mean $\pm \mathrm{SE}$ ). Mean number of ripe seeds per spadix (September) was $3.1 \pm 0.9$ (mean $\pm \mathrm{SE}$ ). Mean seed production in this month was $297 \pm$ 165 seeds $\mathrm{m}^{-2}$ (mean $\pm \mathrm{SD}$ ). Average eelgrass cover in our field plots (September) was estimated to be $4.8 \pm$ $1.1 \%$ (mean $\pm \mathrm{SE}$ ), corresponding to a mean shoot density of $22.6 \pm 5.5$ shoots $\mathrm{m}^{-2}$ (mean $\pm \mathrm{SE}$ ). Average eelgrass cover of the entire meadow (according to the

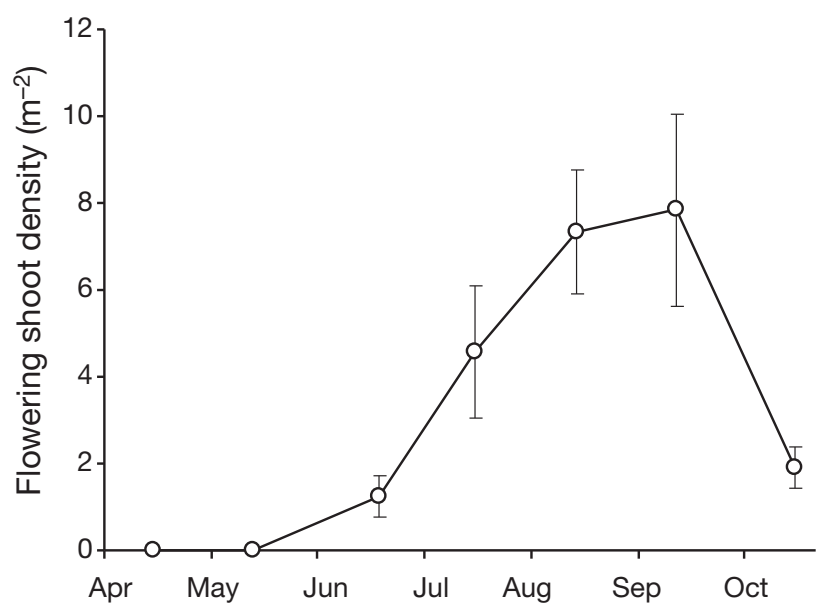

Fig. 2. Zostera marina. Flowering shoot density of eelgrass plants on the Hond/Paap tidal flat in the Ems Estuary during 2003. (Error bars: SE) vegetation map and subsequent ground truthing) was as low as $6.9 \%$. Based on this, the total seed production of this 256 ha eelgrass meadow (not considering longevity, turnover and cumulative formation of flowering shoots) was calculated to be approximately 1094 million seeds per annum.

\section{Wind data}

Wind speed during mid-September to mid-November (1993 to 2002) averaged $4.7 \pm 2.5 \mathrm{~m} \mathrm{~s}^{-1}$ (mean $\pm \mathrm{SD}$ ). South to southwestern winds predominated ( $45 \%$ of the time) during this period, while eastern winds were blowing $16 \%$ of the time (Fig. 3). Winds exceeded $2.5 \mathrm{~m} \mathrm{~s}^{-1}$ during $80 \%$ of the time, $5 \mathrm{~m} \mathrm{~s}^{-1}$ during $40 \%$ of the time, and $10 \mathrm{~m} \mathrm{~s}^{-1}$ during $4 \%$ of the time.

\section{Model sensitivity}

The outcome of model test runs was particularly sensitive to the application of wind drag and, to a smaller degree, to grid resolution and the rate at which flowering eelgrass shoots were introduced into the water column (Table 1). Comparison of different fall velocities of seeds and underlying hydrodynamics (actual or average) yielded only small differences considered negligible at the scale of the transport process simulated in the present modelling study (Table 1). On the basis of these findings, a final model setup was adopted using

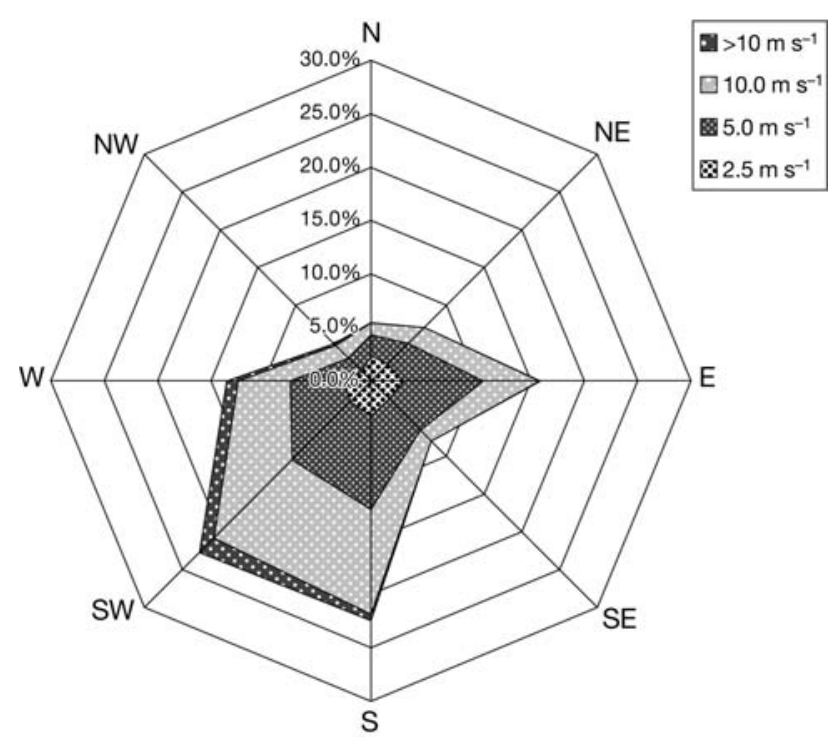

Fig. 3. Wind rose of the study area (Eelde), based on data from 15 September-15 November (averaged for 1993-2002), showing frequency of occurrence of wind directions and wind speeds 
Table 1. Results of the sensitivity testing for 5 main input variables of the model setup, showing RMSE and $r^{2}$ for differences in results between model runs (pair-wise comparison)

\begin{tabular}{|c|c|c|c|}
\hline Parameter & Comparison & RMSE & $\mathrm{r}^{2}$ \\
\hline Grid resolution & $\begin{array}{l}\text { Zunogrof vs. } \\
\text { Zunofijn }\end{array}$ & 0.091 & 0.609 \\
\hline Fall velocity & 20 vs. $200 \mathrm{~m} \mathrm{~d}^{-1}$ & 0.042 & 0.891 \\
\hline Release rate & $\begin{array}{l}\text { At once }(1 \mathrm{~d}) \mathrm{vs} . \\
\text { gradual }(1 \mathrm{mo})\end{array}$ & 0.085 & 0.661 \\
\hline Wind drag & $\begin{array}{l}\text { No wind drag vs. } \\
3 \% \text { wind drag }\end{array}$ & 0.222 & -0.287 \\
\hline Hydrodynamics & Actual vs. average & 0.046 & 0.944 \\
\hline
\end{tabular}
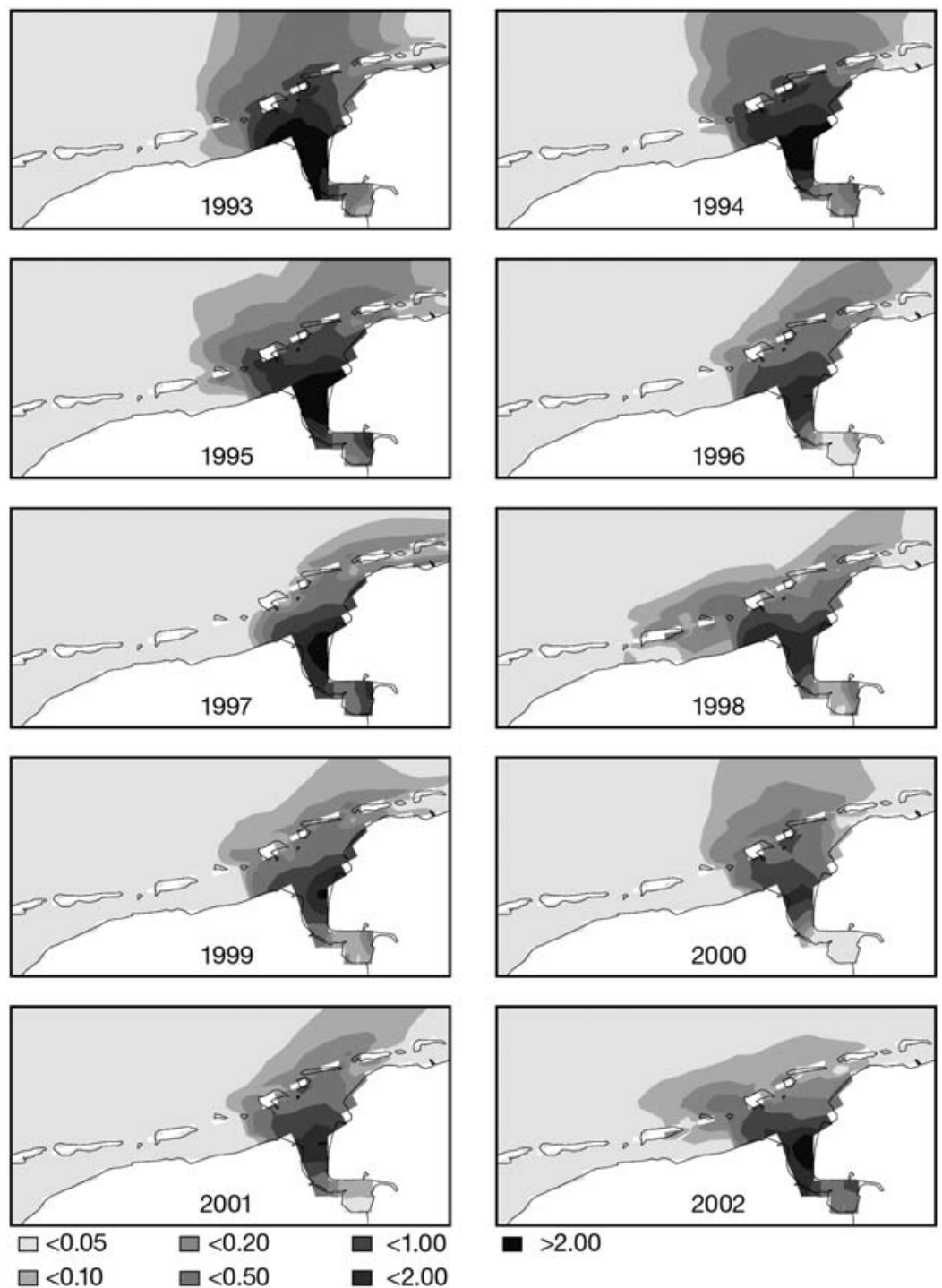

Fig. 4. Zostera marina. Model simulations of potential eelgrass seed-dispersal patterns as a function of meteorological variability using actual wind data from 1993-2002, showing predicted density $\left(\mathrm{m}^{-2}\right)$ of eelgrass seeds on the substrate the model grid ZUNOGROF, a fall velocity for seeds of $200 \mathrm{~m} \mathrm{~d}^{-1}$, a 'gradual release' of flowering shoots into the water (spread out evenly over a 4 wk period), average hydrodynamics and wind drag (surface currents $3 \%$ of actual wind velocity and direction).

\section{Seed transport}

The maximum dispersal distance of eelgrass seeds in these simulations was $129 \mathrm{~km}$ (Fig. 4). Beyond this distance from the source meadow, the density of eelgrass seeds was negligible $\left(<0.1\right.$ seeds $\left.\mathrm{m}^{-2}\right)$. Seed densities $>0.4$ seeds $\mathrm{m}^{-2}$ reached distances of up to $69 \mathrm{~km}$ from the source meadow. Seed densities never reached $>10$ seeds $\mathrm{m}^{-2}$ even at the source meadow (assuming no turnover of flowering shoots and in situ trapping of seeds).

Annual variability in simulated seed distribution was substantial (Fig. 4), which is a reflection of the variability in actual wind conditions (affecting direction and extent of dispersal). Whilst in some years (e.g. 1996 and 1997) seed dispersal has been predominantly in an eastward direction, other years (e.g. 1998 and 2002) show a more even distribution in both western and eastern directions. The mean distribution of seeds (obtained by averaging the results for these years) suggests that the majority of seeds are retained within the estuary, with only limited dispersal towards western parts of the Dutch Wadden Sea (Fig. 5).

\section{Potential for regeneration}

Field data from the eelgrass meadow on the Hond/Paap collected in 2003 suggest that a minimum density of 0.5 seedlings $\mathrm{m}^{-2}$ is required at the start of the growth season (April) to obtain a 1\% cover of eelgrass vegetation by the end of the growth season (September) (Fig. 6). Assuming $100 \%$ success in seed germination and subsequent seedling establishment, a minimum seed density of 0.5 seed $\mathrm{m}^{-2}$ is thus required to obtain $1 \%$ eelgrass cover. Areas that do not meet this criterion (because they receive lower seed densities) may not develop significant eelgrass vegetation, but scat- 


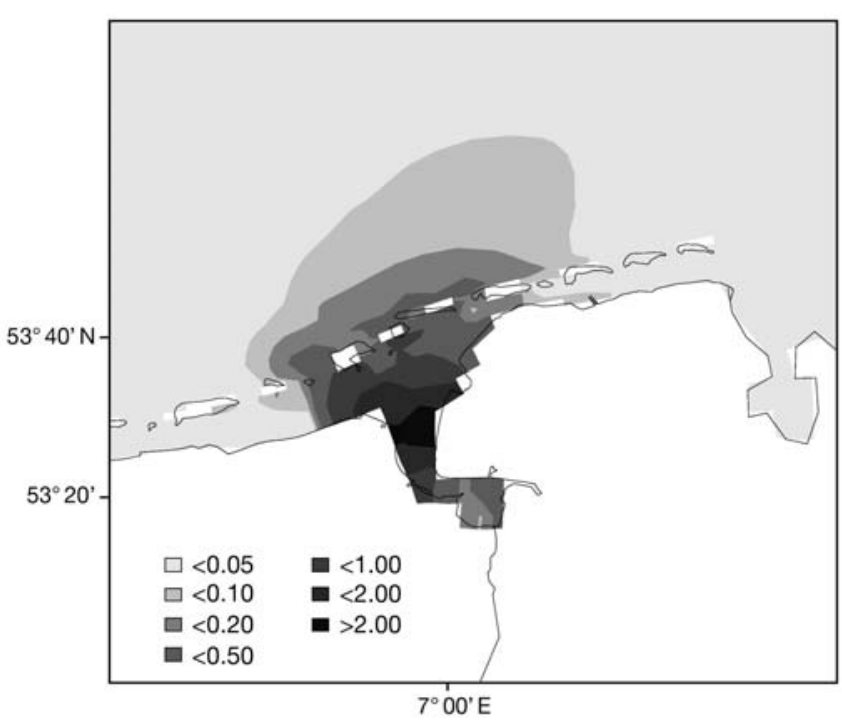

Fig. 5. Zostera marina. Average densities $\left(\mathrm{m}^{-2}\right)$ of eelgrass seeds on the substrate, obtained by averaging the outcome of the model simulations for the years 1993-2002

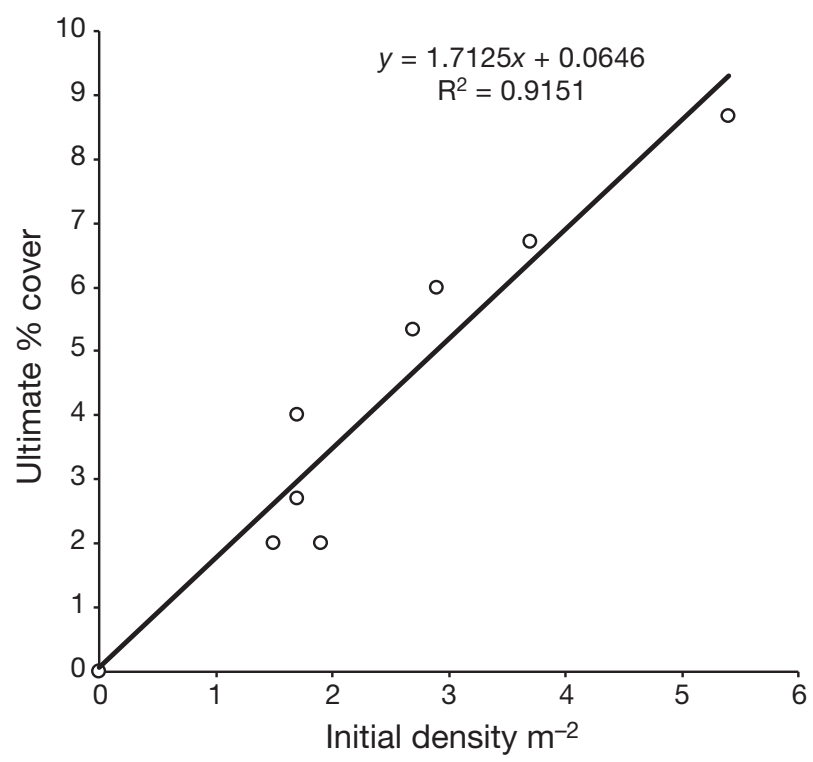

Fig. 6. Zostera marina. Relationship between initial seedling density (April) and ultimate \% cover (September) of eelgrass vegetation on the Hond/Paap in 2003. Points refer to original field data derived from Erftemeijer \& Wijsman (2003). Line represents trendline drawn in Excel

tered individual eelgrass plants may well appear at such sites in certain years. For subsequent use in calculations of colonization potential, the 'seed sufficiency' (i.e. fraction of years in which an area receives seed concentrations $\geq 0.5 \mathrm{~m}^{-2}$ ) to obtain a minimum of $1 \%$ cover of eelgrass vegetation was calculated from the model results.
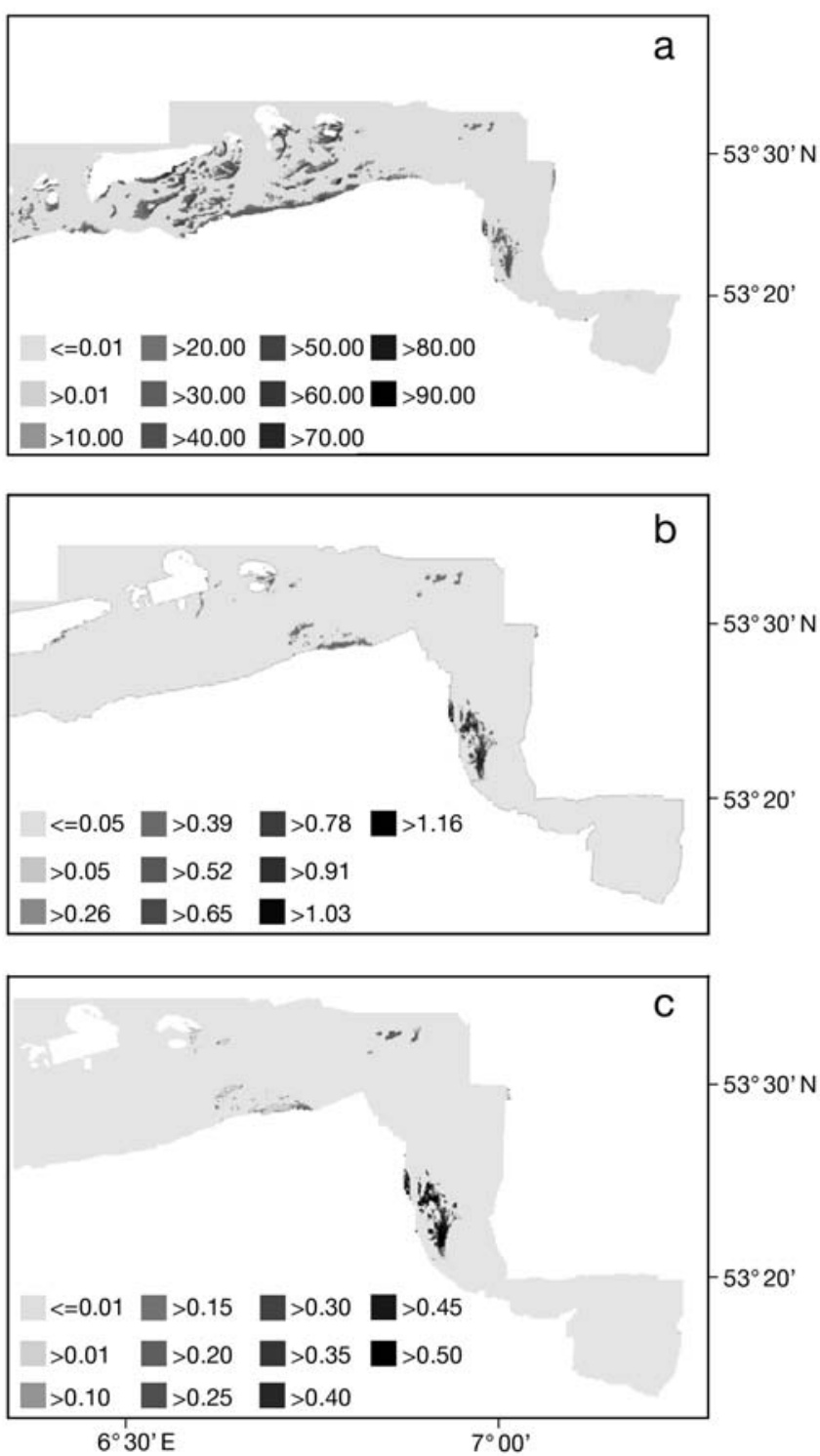

Fig. 7. Zostera marina. Colonization potential in the eastern Dutch Wadden Sea by seed transport from the Hond/Paap population (a) on the basis of predicted eelgrass habitat suitability (adapted from De Jong et al. 2005); (b) calculated by multiplying the habitat suitability index with seed density; and (c) calculated by multiplying seed density with habitat suitability as well as with 'seed sufficiency,' expressed as the fraction of years in which an area receives sufficient seeds (i.e. $\geq 0.5 \mathrm{~m}^{-2}$ ) required to obtain a minimum of $1 \%$ eelgrass cover. Dark areas: suitable areas (a) or areas with significant colonization potential $(\mathrm{b}, \mathrm{c})$

The potential for eelgrass colonization in unvegetated areas in the eastern Dutch Wadden Sea, predicted to be suitable for eelgrass growth (see Fig. 7a), is shown in Fig. $7 b$ (average seed density $\times$ habitat suitability) and Fig. 7c (average seed density $\times$ habitat suitability $\times$ seed sufficiency). 


\section{DISCUSSION}

The results of this modelling study confirm the important potential role of seed dispersal via floating dislodged reproductive shoots for eelgrass colonization of unvegetated sand bottoms and recovery of former eelgrass meadows. The direction and distance of this dispersal mechanism are dependent on prevailing wind conditions determining the advective transport process. The maximum seed-dispersal distance found in this study $(130 \mathrm{~km})$ is comparable to the maximum distance $(100 \mathrm{~km})$ reported by Harwell \& Orth (2002) in a similar study in Chesapeake Bay, and is on the same order of magnitude as dispersal distances of 15 to $23,41,50$ and $60 \mathrm{~km}$ reported for the seeds of the seagrasses Thalassia testudinum and Enhalus acoroides (Kaldy \& Dunton 1999, Lacap et al. 2002), and for the propagules of salt marsh plants (Huiskes et al. 1995) and the mangrove Avicennia marina (Clarke 1993), respectively. These results also agree with recent findings by Olsen et al. (2004) who reported a natural dispersal limit of $\sim 150 \mathrm{~km}$ within the metapopulation based on an observed transition from weak to strong isolation-by-distance in their study on genetic differentiation among northern European eelgrass populations.

Other dispersal mechanisms, such as hydrodynamic transport of seeds (rather than of reproductive shoots), or transport by migratory waterbirds, probably play a relatively insignificant role in the long-distance $(>20 \mathrm{~km})$ dispersal of eelgrass seeds. Investigations on the dispersal of Zostera marina seeds in the field (Chesapeake Bay, USA) and laboratory flume experiments by Orth et al. (1994) suggested that eelgrass seeds settle rapidly, dispersing only up to a few metres under the influence of currents, and become rapidly incorporated into the sediment. A review of longdistance $(>20 \mathrm{~km})$ dispersal of Zostera, Ruppia and Potamogeton seeds by migratory waterbirds through endozoochory (carrying seeds in their guts) in northern Europe revealed that such events are likely to be rare due to a mismatch in timing between peak flowering and bird migration, limited food-retention time in bird stomachs, and differences between habitat types used by waterbirds along their migratory routes (Clausen et al. 2002). Transport of aquatic plant propagules by waterbirds at a local scale over short-to-medium distances $(<20 \mathrm{~km})$, however, is well-documented (Figuerola \& Green 2002).

The spread of eelgrass to areas distant from source populations therefore seems to be primarily a function of detached reproductive shoots with viable seeds being transported over long distances via surface currents (Orth et al. 1994). Field monitoring of the intertidal eelgrass meadow on the Hond/Paap tidal flat during 2003 revealed that the majority of eelgrass flowering shoots are indeed dislodged during autumn storms in late September and October (Erftemeijer \& Wijsman 2003), thus allowing a major proportion of the overall seed production from this meadow to be distributed as floating fraction into the eastern section of the Dutch Wadden Sea.

The current model approach followed a best-case scenario whereby $100 \%$ of all flowering shoots present at the time of peak flowering (September) were assumed to be dislodged (while still containing mature seeds) and released in the water for potential transport. While this may seem to be an overestimation, the total reproductive allocation in eelgrass can be as high as 1.5 to 3.2 times the reproductive shoot biomass at the time of peak flowering (Olesen 1999). For the present study this would mean that the total seed production (per year) of the meadow on the Hond/Paap is probably about twice as high as the 1094 million used in the model runs. In the absence of data from the monitoring of individual (marked) flowering shoots through the September-November period, it is impossible to give reliable quantitative estimates of the proportion of flowering shoots dislodged before seed release relative to the proportion of eelgrass seeds released and sedimented in situ (thus not participating in the long-distance dispersal of floating flowering shoots). The present study results therefore most likely represent a 50:50 scenario, whereby $50 \%$ of the seeds (ca. 1094 million) are retained in situ, while the other $50 \%$ (1094 million seeds) are dispersed into the Wadden Sea, as modelled in this study.

The results of the model simulations indicate that current seed production is sufficient to maintain sustained eelgrass growth on the Hond/Paap intertidal flat and a small part of the Groninger coast (which presently harbour eelgrass growth), regardless of the prevailing wind conditions and even if the entire $(100 \%)$ seed production is dislodged from the meadow in the form of floating reproductive shoots.

The present study further demonstrates that the potential for colonization of other, presently unvegetated, soft substrates (or regeneration of former eelgrass meadows) in the Dutch Wadden Sea through this dispersal mechanism of eelgrass seeds is highly dependent on wind forcing of the surface currents. The main direction of transport under average autumn wind conditions in the study area is northeastward. Easterly winds (occurring at an average frequency of $15 \%$ ) were found to be responsible for some westward transport of eelgrass seeds (at densities $>0.2$ seeds $\mathrm{m}^{-2}$ ) up to $20 \mathrm{~km}$ from the mouth of the estuary.

These results indicate that westward eelgrass colonization of suitable areas in the Dutch Wadden Sea is limited by seed supply due to transport limitations posed by the prevailing hydrodynamic regime. Ex- 
treme events, however, such as prolonged eastern storms, may well be responsible for the occasional transport of eelgrass seeds further westward. Similarly, Kendall et al. (2004) reported on the apparent role of hurricanes in the dispersal of seagrass seeds and plant fragments in the U.S. Virgin Islands. That such episodic events may indeed allow for some natural recovery of former eelgrass vegetations in this part of the Wadden Sea is supported by regular field observations of localised eelgrass patches as far as $40 \mathrm{~km}$ west of the estuary. Furthermore, such eelgrass patches (through flowering and seed distribution) may act as stepping stones for further westward eelgrass colonization in subsequent years.

Besides the wind-driven advective transport of floating reproductive shoots (determining distance and direction of seed dispersal and thus recruitment success), colonization of new eelgrass patches will also be a function of the magnitude of flowering intensity (determining seed output and post-dispersal seed densities) and the suitability of local environmental conditions (determining seedling establishment and survival). Interannual differences in flowering intensity (including pollination and fertilization) in Zostera marina can be significant, especially in intertidal meadows (Van Lent \& Verschuure 1994, Olesen 1999). Field germination of Zostera marina seeds is in the order of 50 to $90 \%$, and up to $40 \%$ of germinated seeds may survive past the seedling stage (Inglis 2000 and various references therein). Suitability of unvegetated areas for (intertidal) seagrass growth is a function of several environmental factors, including emersion period, sediment type, sediment stability, tidal range, turbidity, salinity, climate and fishing pressure (Philippart et al. 1992). Successful establishment and survival of eelgrass seedlings depend in particular on hydrodynamic exposure, sediment type, low-tide water cover and seedling density (Van Katwijk \& Wijgergangs 2004, Bos \& Van Katwijk 2007).

The findings of the present study confirm that hydrodynamic conditions serve as a serious bottleneck for westward seed dispersal, preventing eelgrass (re)colonization of suitable areas in the western part of the Dutch Wadden Sea. In the long term, however, extreme events, such as prolonged eastern storms, may help to overcome this bottleneck and give seeds a chance to travel west and establish. Provided that these seeds reach suitable areas in sufficient densities to enable successful seedling establishment and survival, this could allow for natural recovery of eelgrass in these areas.

Acknowledgements. We gratefully acknowledge the help, support, data provision and critical comments provided by G. Boot, T. Bouma, A. Groeneweg, M. Harwell, F. Kleissen, M. Kuijper, R. J. Orth, F. T. Short, M. de Vries, D. Walker and J. Wijsman. The crew members of the LNV ship 'de Harder', in particular J. de Boer and K. Kruijer, are acknowledged for assistance in the field. We kindly acknowledge the financial support provided for this project by the Ministry of Transport and Public Works within the framework of the WL/Delft Hydraulics R\&D Programme.

\section{LITERATURE CITED}

Bos AR, Van Katwijk MM (2007) Planting density, hydrodynamic exposure and mussel beds affect survival of transplanted intertidal eelgrass. Mar Ecol Prog Ser 336: 121-129

Clarke PJ (1993) Dispersal of grey mangrove (Avicennia marina) propagules in southeastern Australia. Aquat Bot 45:195-204

Clausen P, Nolet BA, Fox AD, Klaassen M (2002) Long-distance endozoochorous dispersal of submerged macrophyte seeds by migratory waterbirds in northern Europe - a critical review of possibilities and limitations. Acta Oecol 23:191-203

De Jong DJ, Van Katwijk MM, Brinkman AG (2005) Kansenkaart zeegras Waddenzee. Potentiële groeimogelijkheden voor zeegras in de Waddenzee. National Institute for Coastal and Marine Management (RIKZ), Middelburg, The Netherlands, April 2004. Report RIKZ/2005.013

De Jonge VN (1995) Wind-driven tidal and annual gross transport of mud and microphytobenthos in the Ems Estuary and its importance for the ecosystem. In: Dyer K, Orth $\mathrm{R}$ (eds) Changes in fluxes in estuaries: implications from science to management. International Symposium Series, Olsen \& Olsen, Fredensborg, p 29-40

$>$ De Jonge VN, De Jong DJ, Van Katwijk MM (2000) Policy plans and management measures to restore eelgrass (Zostera marina L.) in the Dutch Wadden Sea. Helgoland Mar Res 54:151-158

Erftemeijer PLA, Wijsman JWM (2003) Monitoring van vogelstand, zeegrassen en mosselbanken op de Hond/Paap tijdens baggerwerkzaamheden voor het dieper leggen van de Eemszinker (gasleiding) in 2003. Technical Report Z3540, WL/Delft Hydraulics, Delft

Figuerola AV, Green AJ (2002) Dispersal of aquatic organisms by waterbirds: a review of past research and priorities for future studies. Freshw Biol 47:483-494

Giesen WBJT, Van Katwijk MM, Den Hartog C (1990) Eelgrass condition and turbidity in the Dutch Wadden Sea. Aquat Bot 37:71-85

Greve TM, Krause-Jensen D, Rasmussen MB, Christensen PB (2005) Means of rapid eelgrass (Zostera marina L.) recolonisation in former dieback areas. Aquat Bot 82: 143-156

Groeneweg AH (2003) Verslag macrofytobenthos \& zeegraskartering in Oosterschelde en Waddenzee 2002, deels op basis van false colour-luchtfoto's, schaal 1:10,000. Rijskwaterstaat, Meetkundige Dienst, Delft

Harwell MC, Orth RJ (2002) Long-distance dispersal potential in a marine macrophyte. Ecology 83:3319-3330

Hootsmans MJM, Vermaat JE, Van Vierssen W (1987) Seedbank development, germination and early seedling survival of two seagrass species from The Netherlands: Zostera marina L. and Zostera noltii hornem. Aquat Bot 28: $275-285$

Huiskes AHL, Koutstaal BP, Herman PMJ, Beeftink WG, Markusse MM, De Munck W (1995) Seed dispersal of halophytes in tidal salt marshes. J Ecol 83:559-567

Inglis GJ (2000) Variation in the recruitment behaviour of seagrass seeds: implications for population dynamics and resource management. Pac Conserv Biol 5:251-259 
Jager Z, Van Wieringen M, Van Katwijk MM, Van Pelt S (2002) Transplantation of eelgrass (Zostera marina) to the western Dutch Wadden Sea. Wadden Sea Newsl 2002-2:23-25

Kaldy JE, Dunton KH (1999) Ontogenetic photosynthetic changes, dispersal and survival of Thalassia testudinum (turtle grass) seedlings in a sub-tropical lagoon. J Exp Mar Biol Ecol 240:193-212

Kendall MS, Battista T, Hillis-Starr Z (2004) Long term expansion of a deep Syringodium filiforme meadow in St. Croix, US Virgin Islands: the potential role of hurricanes in the dispersal of seeds. Aquat Bot 78:15-25

Lacap CDA, Vermaat JE, Rollon RN, Nacorda HM (2002) Propagule dispersal of the SE Asian seagrasses Enhalus acoroides and Thalassia hemprichii. Mar Ecol Prog Ser 235:75-80

Leendertse JJ (1987) A three-dimensional alternating direction implicit model with iterative fourth-order dissipative non-linear advection terms. WD-3333-NETH, Rijkswaterstaat

Lesser GR, Roelvink JA, Van Kester JATM, Stelling GS (2004) Development and validation of a three-dimensional morphological model. Coast Eng 51:883-915

Luijendijk AP (2001) Validation, calibration and evaluation of Delft3D-FLOW model with ferry measurements. MSc thesis, Delft University of Technology

McMillan C (1991) The longevity of seagrass seeds. Aquat Bot 40:195-198

> Olesen B (1999) Reproduction in Danish eelgrass (Zostera marina L.) stands: Size-dependence and biomass partitioning. Aquat Bot 65:209-219

Olsen JL, Stam WT, Coyer JA (2004) North Atlantic phylogeography and large-scale population differentiation of the seagrass Zostera marina L. Mol Ecol 13:1923-1941

Orth RJ, Luckenbach M, Moore KA (1994) Seed dispersal in a marine macrophyte: implications for colonization and restoration. Ecology 75:1927-1939

Orth RJ, Harwell MC, Bailey EM, Bartholomew A and others (2000) A review of issues in seagrass seed dormancy and germination: implications for conservation and restoration. Mar Ecol Prog Ser 200:277-288

Orth RJ, Harwell MC, Inglis GJ (2006). Ecology of seagrass seeds and seagrass dispersal processes. In: Larkum AWD, Orth RJ, Duarte CM (eds) Seagrasses: biology, ecology and evolution. Springer, Dordrecht, p 111-133

Ouboter MRL, Van Eck BTM, Van Gils JAG, Sweerts JP, Villars MT (1997) Water quality modelling of the western Scheldt estuary. Hydrobiologia 366:129-142

Patterson MR, Harwell MC, Orth LM, Orth RJ (2001) Biomechanical properties of the reproductive shoots of eelgrass. Aquat Bot 69:27-40

Editorial responsibility: Howard Browman, Storebø, Norway
Philippart CJM, Dijkema KS, Van der Meer J (1992) Wadden Sea seagrasses: where and why? Neth Inst Sea Res Publ Ser 20:177-191

Reed M, Johansen O, Brandvik PJ, Daling P and others (1999) Oil spill modelling towards the close of the 20th century: overview of the state of the art. Spill Sci Technol B 5:3-16

Roelvink JA, Van Banning GKFM (1994) Design and development of Delft3D and application to coastal morphodynamics. In: Verwey A, Minns AW, Babovic V (eds) Proceedings hydroinformatics 1994. Balkema, Rotterdam, p 451-456

Roelvink JA, Van der Kaaij T, Ruessink G (2001) Calibration and verification of large-scale 2D/3D flow models phase 1. Sub-product 2, MARE report, reference Z3029.11, WL/Delft Hydraulics, Delft

Sammarco PW, Heron ML (1994) The bio-physics of marine larval dispersal. Coastal and Estuarine Studies 45, American Geophysical Union, Washington, DC

Short FT, Coles RG (eds) (2001) Global seagrass research methods. Elsevier, Amsterdam

Sokal RS, Rohlf FJ (1995) Biometry. The principles and practice of statistics in biological research. Freeman, New York

Stelling GS (1983) On the construction of computational methods for shallow water flow problems. PhD thesis, Delft University of Technology

Stelling GS, Van Kester TJA (1994) On the approximation of horizontal gradients in sigma coordinates for bathymetry with steep bottom slopes. Int J Numer Meth Fl 18:915-935

Thiel M, Haye PA (2006) The ecology of rafting in the marine environment. III. Biogeographical and evolutionary consequences. Oceanogr Mar Biol Annu Rev 44:323-429

Tsanis IK (1989) Simulation of wind-induced water currents. J Hydraul Eng 115:1113-1134

Van der Molen DT, Los FJ, Van Ballegooijen L, Van der Vat MP (1994) Mathematical modelling as a tool for management in eutrophication control of shallow lakes. Hydrobiologia 275/276:479-492

Van Gils JAG, Ouboter MRL, De Rooij NM (1993) Modelling of water sediment quality in the Scheldt Estuary. Neth J Aquat Ecol 27:257-265

Van Goor ACJ (1919) Het zeegras (Zostera marina L.) en zijn beteekenis voor het leven der visschen. Rapp Verh Rijksinst Visserij 1:415-498

Van Katwijk MM, Wijgergangs LJM (2004) Effects of locally varying exposure, sediment type and low-tide water cover on Zostera marina recruitment from seed. Aquat Bot 80: $1-12$

Van Lent F, Verschuure JM (1994) Intraspecific variability of Zostera marina L. (eelgrass) in the estuaries and lagoons of the southwestern Netherlands. I. Population dynamics. Aquat Bot 48:31-58

Submitted: September 11, 2006; Accepted: October 23, 2007 Proofs received from author(s): March 26, 2008 